\title{
APPLICATION OF THE END POINT POLYMERASE CHAIN REACTION METHOD TO THE DETECTION OF CERTAIN MILK-BORNE BACTERIA
}

Nassib, T. A. ${ }^{1}$, W. M. El-Sharoud ${ }^{1}$, E. A. Essawy ${ }^{2}$ and Aliaa A. Darwish ${ }^{2}$

${ }^{1}$ Dairy Department, Faculty of Agriculture, Mansoura University

2 Dairy Department, Food Technology Research Institute, Agricultural Research Center, Giza, Egypt

\begin{abstract}
The polymerase chain reaction (PCR) is a modern method that could differentiate microorganisms from each other by detecting certain DNA sequences uniquely associated with each species. This study aimed to develop a relevant end point PCR assay to detect Salmonella ser. Typhimurium in milk. To pursue this objective, the conditions of both DNA extraction and PCR reactions were developed in terms of the boiling time for DNA extraction and primer concentration for the PCR assay. Results showed that all of the three examined boiling times of 10,15 and 20 min were equally effective for carrying out efficient DNA extraction. PCR reaction mixture involving a primer concentration of $1300 \mathrm{nM}$ was the most efficient concentration, compared to $650 \mathrm{nM}$, and $325 \mathrm{nM}$ for detecting Salmonella ser. Typhimurium. The sensitivity of the developed PCR method to detect different viable numbers of Salmonella Typhimurium in tryptone soya broth (TSB) and reconstituted skim milk (RSM) was examined. The PCR assay was able to detect $10^{9}, 10^{8}, 10^{7}$, and $10^{6} \mathrm{cfu} \mathrm{\textrm {mL } ^ { - 1 }}$ of Salmonella in TSB. Whereas, it could detect $10^{9}$, and $10^{8} \mathrm{cfu} \mathrm{mL}^{-1}$ of Salmonella in RSM. These results suggested that the developed PCR method had higher sensitivity to detect Salmonella in TSB, compared to RSM. This was attributed to some milk components that could be inhibitory to PCR reactions.
\end{abstract}

Keywords: Salmonella ser. Typhimurium, PCR assay, boiling time, primer concentration.

\section{INTRODUCTION}

Despite the advancement in food safety approaches, food-borne Salmonella continues as a leading causative agent of gastroenteritis worldwide (D'Aoust, 2000; Pui et al., 2011 a \& b; Scallan et al., 2011). Salmonella is usually transmitted via foods from animal sources including milk, dairy products, poultry and egg. Developing highly sensitive, rapid methods for detecting Salmonella is an effective measure to ensure the eradication of this pathogen from foodstuffs (Baia et al., 2013). Traditional culture-based methods are highly reliable for detecting Salmonella in food products, but they require 3-4 days for their completion (Mercanoglu and Griffiths, 2005).

The polymerase chain reaction (PCR) method is a sensitive molecularbased protocol that has proved to speed up the detection process of foodborne pathogens (Bruce, 1994; Hill, 1996 and Wang et al., 1997). It relies on the amplification and detection of DNA sequences that are unique to each bacterial species. In its end point format, PCR involves DNA extraction from 
cells, followed by amplification of a certain DNA sequence, if present, and gel electrophoresis detection of the amplified product. However, the application of PCR to the detection of bacterial pathogens requires optimization steps aimed at adapting the protocol to the examined microorganism and food products. The present study was thus designed to optimize the boiling time for DNA extraction from Salmonella cells, and primer concentration used for DNA amplification. The study also examined the efficiency of the developed PCR protocol for the detection of Salmonella in a synthetic culture medium and reconstituted skim milk.

\section{MATERIALS AND METHODS}

\section{Cultures and growth conditions}

Salmonella ser. Typhimurium was used throughout the whole study. $S$. Typhimurium was maintained on plates of tryptone soya agar (TSA) (Oxoid, Basingstoke, UK) at $4^{\circ} \mathrm{C}$. Prior to each use, a single colony of $S$. Typhimurium was inoculated into tryptone soya broth (TSB) (Oxoid), followed by incubation at $37^{\circ} \mathrm{C}$ for $24 \mathrm{~h}$.

\section{End point polymerase chain reaction (PCR) analysis}

End point PCR analysis of $S$. Typhimurium involved three stages of a) DNA extraction, b) PCR amplification, and c) agarose gel electrophoresis. These stages were conducted as follows:

\section{DNA extraction}

The boiling in water method was used to extract DNA from $S$. Typhimurium cultures in TSB. Briefly, $1 \mathrm{~mL}$ of each Salmonella culture was centrifuged at 14,000 rpm for 10 min using a bench centrifuge (Hettich, Aulendorf, Germany). Cell pellet was re-suspended in $100 \mu \mathrm{l}$ sterilized distilled water and incubated at $100^{\circ} \mathrm{C}$ in dry heating block (Cleaver Scientific Ltd, Swift Valley Rugby, UK) for $10 \mathrm{~min}, 15 \mathrm{~min}$, and $20 \mathrm{~min}$. Samples were cooled for $2 \mathrm{~min}$ at room temperature and centrifuged at $14,000 \mathrm{rpm}$ for 10 min. DNA containing supernatant was collected and preserved at $-20^{\circ} \mathrm{C}$ until use.

\section{PCR amplification}

DNA extracted from Salmonella was subjected to PCR amplification targeting the invasive gene (invA) (Rahn et al. 1992). This involved using the invA-1 (5'-GTG AAATTA TCG CCA CGT TCG GGC AA-3') and invA-2 (5'-TCATCG CAC CGT CAA AGG AAC C-3') primers. PCR was conducted using a reaction mixture of a total volume of $15 \mu \mathrm{L}$ consisting of $7.5 \mu \mathrm{l}$ master mix (OneTaq Quick-Load 2X, New England Biolabs, UK), $2 \mu$ of each of invA-1 (forward primer), and invA-2 (reverse primer) to give different concentrations of $1300 \mathrm{nM}, 650 \mathrm{nM}$, and $325 \mathrm{nM}, 3 \mu \mathrm{l}$ DNA template extracted from Salmonella, and $0.5 \mu \mathrm{l}$ sterilized distilled water. PCR reactions were conducted employing the conditions described by Rahn et al. (1992) and Mercanoglu and Griffiths (2005) with some modifications as follows. PCR reaction mixture was initially heated at $50^{\circ} \mathrm{C}$ for $2 \mathrm{~min}$, followed by $95{ }^{\circ} \mathrm{C}$ for $10 \mathrm{~min}$ and $45 \mathrm{cycles}$ of $95^{\circ} \mathrm{C}$ for $30 \mathrm{~s}, 65^{\circ} \mathrm{C}$ for $1 \mathrm{~min}$, and $72{ }^{\circ} \mathrm{C}$ for $2 \mathrm{~min}$. 
PCR reactions were conducted using the Primus 25 Advanced® PCR thermal cycler (PEQLAB Biotechnology GmbH, Erlangen, Germany).

\section{Agarose gel electrophoresis}

PCR amplified DNA product (amplicon) of different samples was examined using agarose gel electrophoresis as follows. Samples of $10 \mu \mathrm{l}$ of each amplicon was electrophoresed on $2 \%(\mathrm{w} / \mathrm{v})$ agarose gel in TBE buffer (1x) for $40 \mathrm{~min}$ at $110 \mathrm{~V}$. Separated bands were visualized and photographed using the BioDocAnalyzer gel documentation system (Biometra, Goettinge, Germany).

\section{RESULTS AND DISCUSSION}

\section{Optimizing the boiling time for DNA extraction for PCR detection of Salmonella ser. Typhimurium}

The effect of different boiling times used for DNA extraction on the efficiency of PCR was assessed. DNA was extracted from a $24 \mathrm{~h}$ culture of $S$. ser. Typhimurim using different boiling times of $10 \mathrm{~min}, 15 \mathrm{~min}$, and $20 \mathrm{~min}$, and subjected to PCR analysis targeting the invA gene. PCR amplicons were then analysed using agarose gel electrophoresis. Figure 1 shows the results of the gel electrophoresis. It could be seen that all treatments resulted in resolving a DNA band of the size $284 \mathrm{bp}$. This was the expected size of the DNA amplicon resulting from PCR amplification of the targeted fragment of the invA gene (Rahn et al. 1992). This indicated that all of the three boiling times of $10 \mathrm{~min}, 15 \mathrm{~min}$, and $20 \mathrm{~min}$ were equally efficient in DNA extraction. One of these three boiling times, $15 \mathrm{~min}$, was thus used in the next experiments.

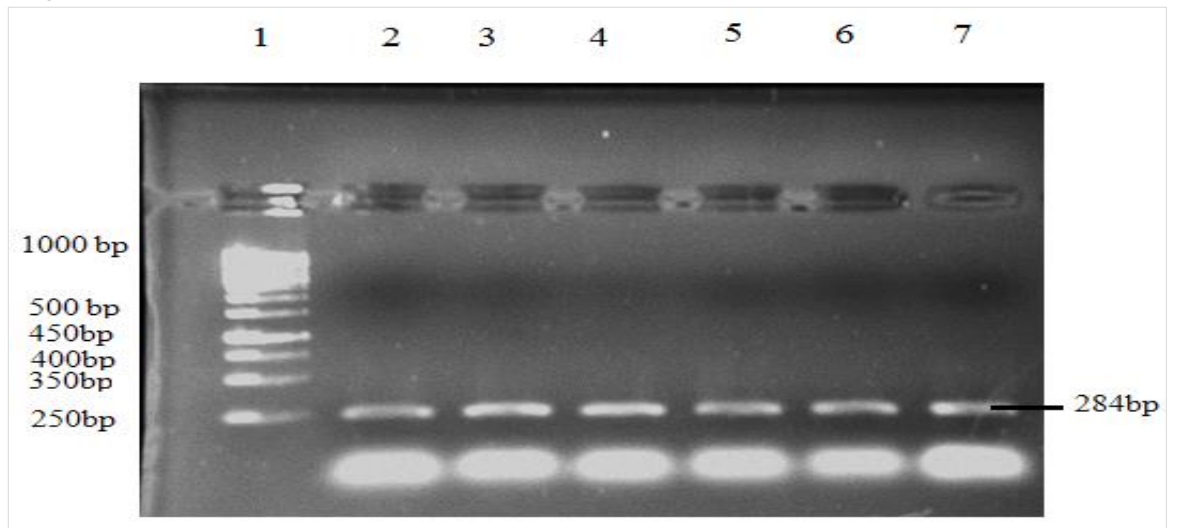

Figure 1: Effect of different boiling times used for DNA extraction on the efficiency of end point PCR detection of $S$. Typhimurium. Lane 1: DNA ladder (250 bp - 1000 bp), lanes 2 \& 3: PCR amplicons using $10 \mathrm{~min}$ boiling, lane 4 \& 5: PCR amplicons using $15 \mathrm{~min}$, and lane 6 \& 7: PCR amplicons using $20 \mathrm{~min}$. 
Optimization of primer concentration in the PCR reaction for the detection of Salmonella ser. Typhimurium

The concentration of the forward and reverse primers (invA-1 and invA2, respectivley) used for PCR detection targeting the invA gene in Salmonella ser. Typhimurium was optimized. DNA was extracted from a $24 \mathrm{~h}$ culture of Salmonella ser. Typhimurium by boiling for $15 \mathrm{~min}$. Extracted DNA was then subjected to end point PCR analysis using different concentrations of 1300 $\mathrm{nM}, 650 \mathrm{nM}$, and $325 \mathrm{nM}$ of each of the invA-1 and invA-2 primers. Figure 2 shows the results of the gel electrophoresis of PCR amplification using different primer concentrations. It could be seen that only the PCR reaction mixture involving a primer concentration of $1300 \mathrm{nM}$ produced a $284 \mathrm{bp}$ DNA band. This represented the expected size of the DNA amplicon resulting from PCR amplification of the targeted fragment of the invA gene (Rahn et al. 1992). Whereas, the $650 \mathrm{nM}$, and $325 \mathrm{nM}$ primer concentrations did not give any positive results. It could thus be concluded that the primer concentration of $1300 \mathrm{nM}$ was the most efficient concentration compared to $650 \mathrm{nM}$, and $325 \mathrm{nM}$ for the end point PCR detection of Salmonella ser. Typhimurim.

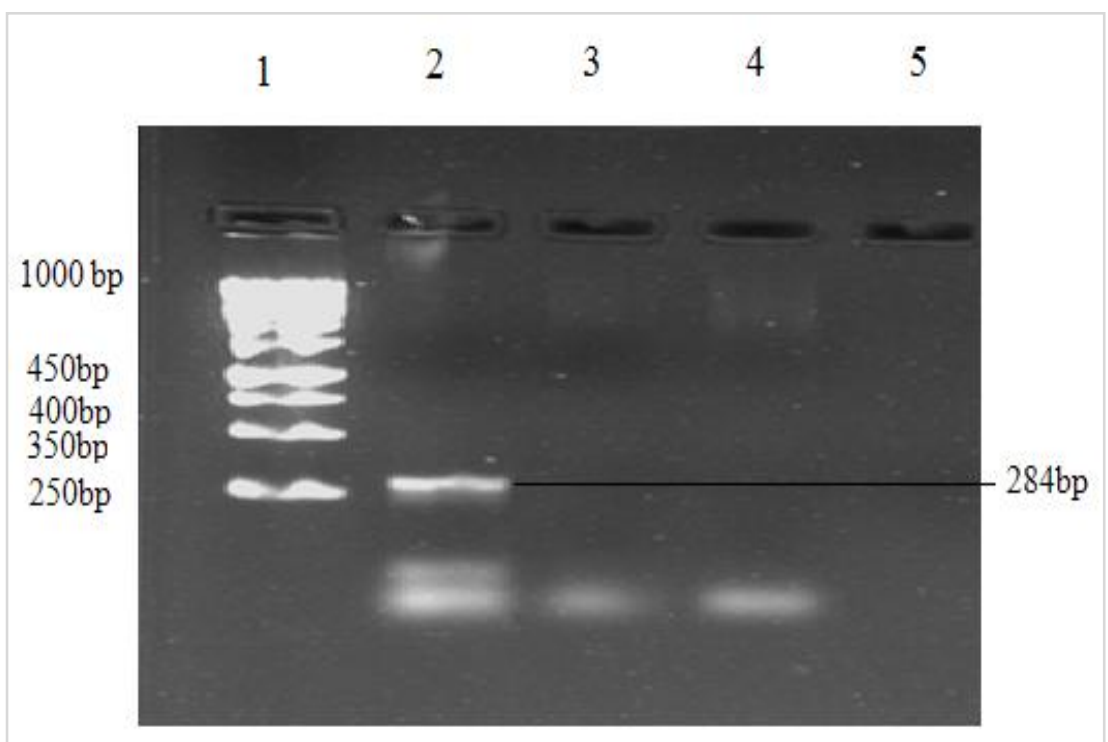

Figure 2: Effect of different primer concentrations on the efficiency of end point PCR detection of $S$ Typhimurium. Lane 1: DNA ladder (250 bp - $1000 \mathrm{bp}$ ), lane 2: PCR amplicon using $1300 \mathrm{nM}$ of each primer, lane 3: PCR amplicon using $650 \mathrm{nM}$ of each primer, and lane 4: PCR amplicon using $325 \mathrm{nM}$ of each primer. 
Sensitivity of the end point PCR method to detect various viable numbers of Salmonella in a synthetic culture medium and reconstituted skim milk

The sensitivity of the optimized end point PCR method to detect different viable numbers of Salmonella Typhimurium in tryptone soya broth (TSB) and reconstituted skim milk (RSM) was examined. A $24 \mathrm{~h}$ culture of Salmonella was serially diluted in TSB and RSM to provide viable numbers

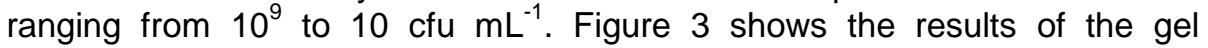
electrophoresis of PCR amplification of different concentrations of Salmonella in TSB. It could be seen that a DNA band of the size of the targeted sequence of the invA gene, i.e. $284 \mathrm{bp}$, could be detected in PCR amplicons

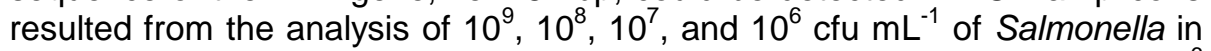
TSB. No positive results could be observed with cell numbers lower than $10^{6}$ cfu $\mathrm{mL}^{-1}$ of Salmonella (figure 3). This suggested that the minimum detection level of Salmonella in TSB by the end point PCR method was $10^{6} \mathrm{cfu} \mathrm{mL}^{-1}$.

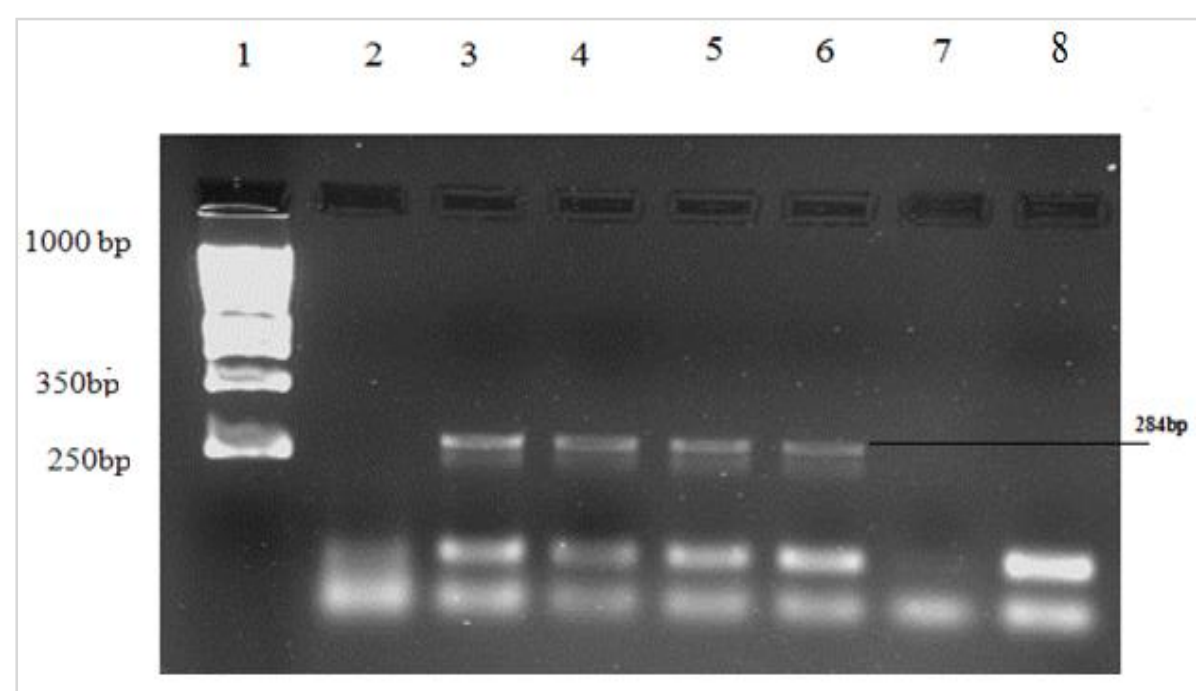

Figure 3: PCR Detection of different viable numbers of $S$. Typhimurium in TSB. Lane 1: DNA ladder (250 bp - $1000 \mathrm{bp}$ ), lanes 3, 4, 5, and 6: PCR amplicons of $10^{9} \mathrm{cfu} \mathrm{mL}-1,10^{8} \mathrm{cfu} \mathrm{mL}^{-1} 10^{7} \mathrm{cfu}$ $\mathrm{mL}^{-1}$, and $10^{6} \mathrm{cfu} \mathrm{mL} \mathrm{m}^{-1}$ of Salmonella in TSB, respectively,

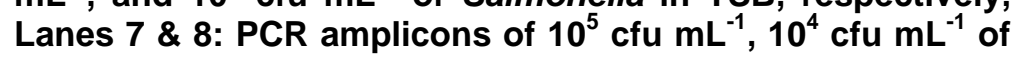
Salmonella in TSB, respectively.

The use of the same end point PCR method to detect Salmonella in reconstituted skim milk (RSM) generated a higher detection level. It could be noted in Figure 4 that only two positive DNA bands of the size $284 \mathrm{bp}$ were detected in PCR amplicons resulted from the analysis of $10^{9}$ and $10^{8} \mathrm{cfu} \mathrm{mL}^{-1}$ of Salmonella in RSM. No positive results could be reported with viable numbers lower than $10^{8} \mathrm{cfu} \mathrm{\textrm {mL } ^ { - 1 }}$. Attempts to improve the sensitivity of the 
assay using $10 \mathrm{~mL}$ of RSM cultures containing Salmonella rather than $1 \mathrm{~mL}$ for DNA extraction were unsuccessful. Figure 5 shows the results of the analysis of $10 \mathrm{~mL}$ samples of RSM containing different viable numbers of Salmonella. It could be seen that no improvement could be observed with the higher sample volume of $10 \mathrm{~mL}$ since positive DNA bands were only observed with the analysis of $10^{9}$ and $10^{8} \mathrm{cfu} \mathrm{mL}^{-1}$. This indicated that the sensitivity of the end point PCR method to detect Salmonella in RSM was lower compared to TSB. This could be attributed to the presence of macromolecules like proteins and fat in milk, which might interfere with the PCR assay (Oliveira and Lencastre, 2002). However, Bickley et al. (1996) reported that PCR inhibition in milk samples is mainly dependant on the concentration of calcium, whereas the fat content seems to have only minor influence on the amplification efficiency. Powell et al. (1994) have also identified plasmin as a natural PCR inhibitor in milk that could degrade the Taq polymerase.

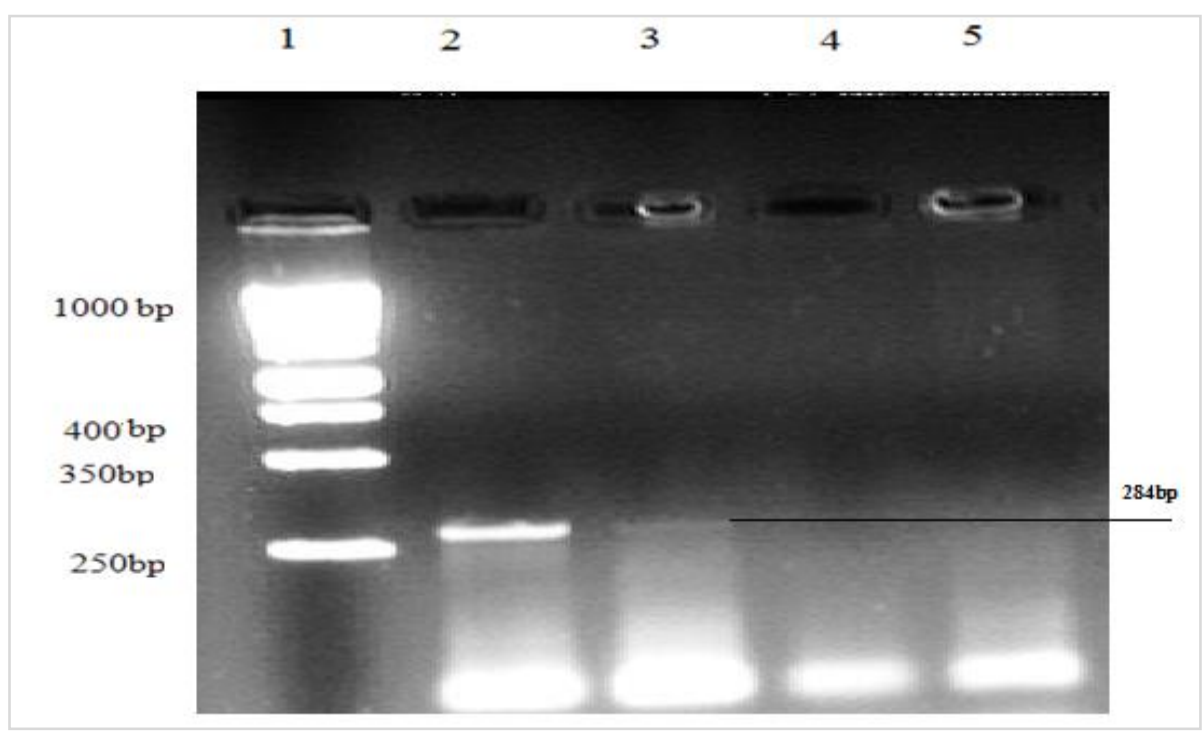

Figure 4: PCR Detection of different viable numbers of $S$. Typhimurium in reconstituted skim milk, using $1 \mathrm{~mL}$ samples. Lane 1: DNA ladder (250 bp - $1000 \mathrm{bp})$, lanes 2 \& 3 : PCR amplicons of $10^{9}$

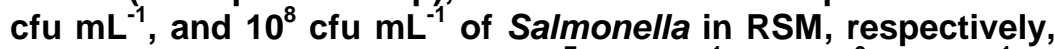
lanes 4 \& 5: PCR amplicons of $10^{7} \mathrm{cfu} \mathrm{mL}^{-1}$, and $10^{6} \mathrm{cfu} \mathrm{mL}^{-1}$ of Salmonella in RSM, respectively. 


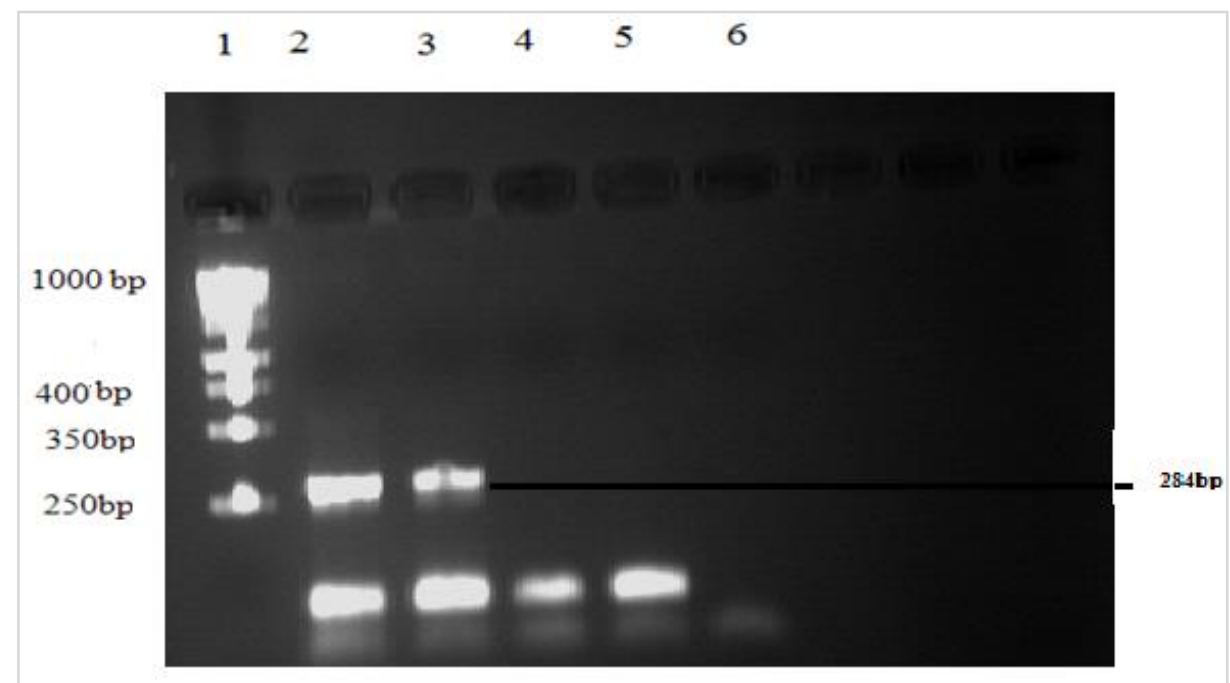

Figure 5: PCR Detection of different viable numbers of $S$. Typhimurium in reconstituted skim milk, using $10 \mathrm{~mL}$ samples. Lane 1: DNA ladder (250 bp - $1000 \mathrm{bp})$, lanes 2 \& 3: PCR amplicons of $10^{9}$ cfu $\mathrm{mL}^{-1}$, and $10^{8} \mathrm{cfu} \mathrm{mL}^{-1}$ of Salmonella in RSM, respectively, lanes 4, 5 \& 6: PCR amplicons of $10^{7} \mathrm{cfu} \mathrm{mL}^{-1}, 10^{6} \mathrm{cfu} \mathrm{mL}^{-1}$, and $10^{5}$ cfu mL ${ }^{-1}$ of Salmonella in RSM, respectively.

\section{REFERENCE}

Baia, Y., Songa, M., Cuia, Y., Shia, C., Wanga, D., Paolib, G. C., and Shia, X. (2013). A rapid method for the detection of food-borne pathogens by extraction of a trace amount of DNA from raw milk based on aminomodified silica-coated magnetic nanoparticles and polymerase chain reaction. Analytica Chimica Acta 787: 93-101.

Bickley, J., Short, J. K., McDowell, D. G., and Parkes, H. C. (1996). Polymerase chain reaction (PCR) detection of Listeria monocytogenes in diluted milk and reversal of PCR inhibition caused by calcium ions. Letters in Applied Microbiology 22:153-158.

Bruce, I. J. (1994). Nucleic acid amplification mediated microbial identification. Science Progress 77: 183-206.

D'Aoust, J-Y. (2000). Salmonella. In The Microbiological Safety and Quality of Food, pp 1233-1299. Lund B M, Baird-Parker T C and Gould G W, eds. Maryland: Aspen Publishers, Inc.

Hill, W. E. (1996). The polymerase chain reaction: application for the detection of foodborne pathogen. Critical Reviews in Food Science and Nutrition 36: 123-173.

Mercanoglu, B. and Griffiths, M. W.(2005).Combination of immunomagnetic separation with real-time PCR for rapid detection of Salmonella in milk, ground beef,and alfalfa sprouts. Journal of Food Protection 68:557-561. 
Oliveira, D. C. and Lencastre, H. (2002). Multiplex PCR strategy for rapid identification of structural types and variants of the mec element in methicillin-resistant Staphylococcus aureus. Antimicrobial Agents and Chemotherapy 46: 2155-2161.

Powell, H. A., Gooding, C. M., Garrett, S. D., Lund, B. M., and McKee, R. A. (1994). Proteinase inhibition of the detection of listeria monocytogenes in milk using the polymerase chain reaction. Letters in Applied Microbiology 18: 59-61.

Pui, C. F., Wong, W. C., Chai, L. C., Nillian, E., Ghazali, F. M., Cheah, Y. K., Nakaguchi, Y., Nishibuchi, M., and Radu, S. (2011a). Simultaneous detection of Salmonella spp, Salmonella Typhi and Salmonella Typhimurium in sliced fruits using multiplex PCR. Food Control 22: 337-342.

Pui, C. F., Wong, W. C., Chai, L. C., Tunung, R., Jeyaletchumi, P., Noor Hidayah, M.S., Ubong, A., Farinazleen, M.G., Cheah, Y.K., and Son, R. (2011b). Salmonella: a foodborne pathogen. International Food Research Journal 18: 465-473.

Rahn, K., De Grandis, S. A., Clarke, R. C., McEwen, S. A., Galan, J. E., Ginocchio, C., Curtis, R., and Gyles. C. L. (1992). Amplification of an invA gene sequence of Salmonella Typhimurium by polymerase chain reaction as a specific method of detection of Salmonella. Molecular and Cellular Probes 6: 271-279

Scallan, E., Hoekstra, R. M., Angulo, F. J., Tauxe, R. V., Widdowson, M. A., Roy, S. L., Jones, J. L., Griffin, and P. M. (2011). Food-borne illness acquired in the United States-major pathogens. Emerging Infectious Diseases 17: 7-15.

Wang, R. F., Cao, W. W., and Ceniglia, C. E. (1997). A universal protocol for PCR detection of 13 species of foodborne pathogens in foods. Journal of Applied Microbiology 83: 727-736. 
إستخدام طريقة تفاعل البلمرة المتسلسل في الكثف عن أنـواع معينه من البكتريـا

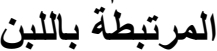

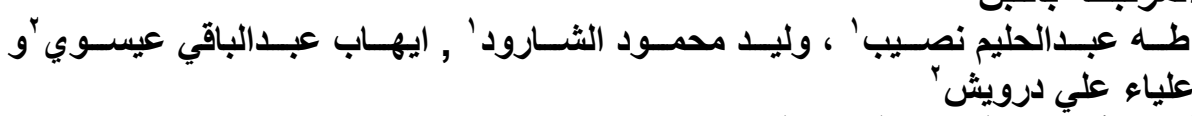

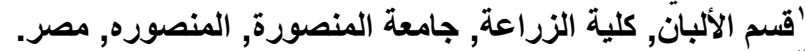

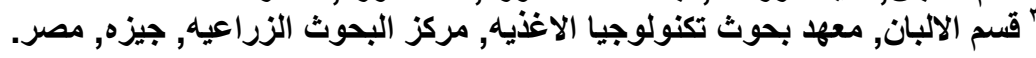

تفاعل السلسلة المتبلمر (PCR) هو طريقة حديثة يمكن إستخدامها في التمييز بين الميكروبات وذلك ونكا

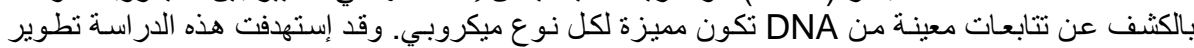

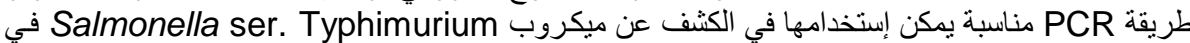

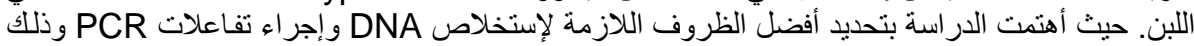

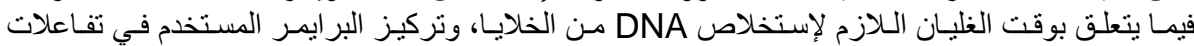

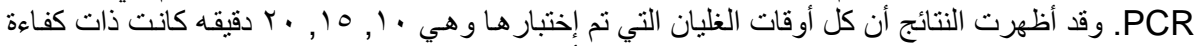

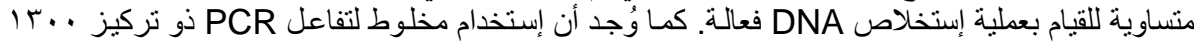

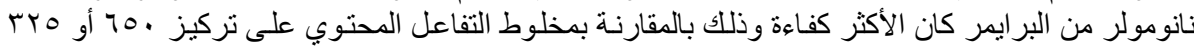

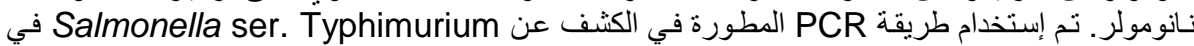

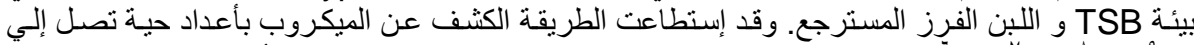

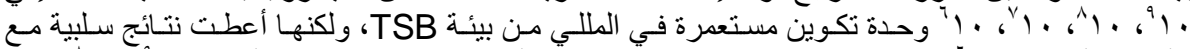

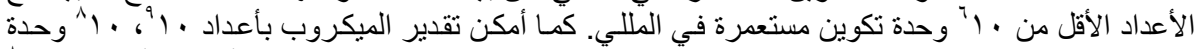

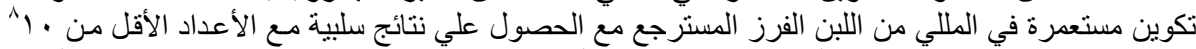

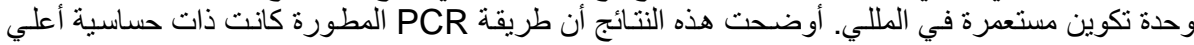

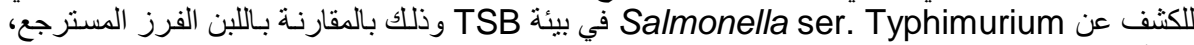
وقد أعزي ذلك إلي امكانية تثيبط تفاعل PCR بواسطة بعض المركبات اللبنية. 